\title{
Evaporation Plant for Recycling of Caustic Soda
}

\author{
Emin Taner ELMAS*
}

\author{
*Department of Energy Systems Engineering, Faculty of Engineering And Natural Sciences, \\ İskenderun Technical University (İSTE), Main Campus 31200 , İskenderun / Hatay - TURKEY \\ Tel: +90(0) 5437336421 \\ (taner.elmas@iste.edu.tr)
}

Received: 28.07.2017 Accepted: 22.09.2017

\begin{abstract}
The most important problem that humanity is expected to face in the coming century shall be environmental pollution. On one hand, the population of human beings are using natural resources rapidly, on the other hand, they are adding hundreds of pollutants in the form of metals, acids, bases and etc. Thus, they have created an abnormal situation which has resulted in an imbalance in the natural systems.
\end{abstract}

As the industrialization improves, it creates pollution and also it creates jobs for the people. Especially in developed countries, for instance European countries and U.S.A. there are also many stringent restrictions for the environmental pollution, and there are many laws, political arrangements. Of course, a pollution free environment will require a high cost, often an expensive operation. However, it is much costlier trying to undo the damage done. On the basis of concept tried to mention above human beings have studied on the subjects related with environmental pollution. They have established waste water treatment plants, many kinds of recycling and recovery plants, and etc.

In this study, it has been tried to establish such an idea that a pollution free environment may be available if this technical process is used properly. So, the first goal of this study is to provide a concise statement of the requirements and opportunities for obtaining environmental benefits. The second objective will be to provide economical savings while providing the environmental benefits at the same time. To emphasize the great importance of above mentioned subjects the application of recycle technology for the sodium hydroxide $(\mathrm{NaOH})$, which is named as caustic soda in industrial processes, realized by means of an evaporation plant is used. Caustic soda is used in textile industry for mercerizing process as it is used in many different processes. To give the cotton more strength and to obtain a smoother surface and an improved affinity the mercerizing is essential. After being finished the mercerizing operation, generally the process solution (containing caustic soda) is discharged to the environment, e.g., rivers, seas and sewage. In spite of the fact that this application is widely spread in use, it is forbidden in all developed countries to discharge the caustic soda solutions even at a $1 \%$ concentration since the caustic soda is highly basic (highly alkaline). For this reason, it is very harmful for the environment. It is possible to extract 
the caustic soda from the caustic soda solutions before discharging it to the environment for preventing the harms of this material. The washing water containing $\mathrm{NaOH}$ will be concentrated by $\mathrm{H}_{2} \mathrm{O}$ evaporation and shall be recycled in the mercerizing system. The concentration may take place in a single or multiple - stage (double-stage) installation under vacuum or atmospheric pressure.

The washing water to be concentrated is moved from the storage tank to the first evaporation stage and the thermal energy for evaporation operation is added by the steam. The vapor coming from the first evaporation stage is used for the next evaporation stage as the heating steam of this unit. The vapor from the last stage is condensed in a condenser. The condensed vapor can be safely discharged and the concentrated caustic soda can be reused for the subsequent mercerizing operation. So, both economical profits and environmental benefits can be provided by reusing the caustic soda for next processes, after it is recovered by the help of this way. Desalination unit in Jeddah which is the capital city of Saudi Arabia, is an example for this kind of operations. This plant was established 1970's and has been used as both a power station and a desalination unit. At this plant the exhaust steam coming from the steam turbines is used as the heating steam for evaporators of desalination unit. Unfortunately, in our country, even in İzmir, the waste water of textile industry is discharged to the environment. Because, the environmental laws are not adequate and the enterprisers think that a recycling plant is not an economical investment. However, it is stated in this study that such a concept is not right. It has been tried to show that such an investment, i.e., "An Evaporation Plant for Recycling of Caustic Soda" may be profitable if it is installed and operated properly, and also it has been tried to increase the attractively of these kinds of plants. It is hoped that, the laws and stringent restrictions related with environment shall be arranged, so that we shall live in a healthy world.

Keywords Evaporation, Recycling, Caustic soda, Sodium hydroxide, Vacuum, Steam

\section{NOMENCLATURE}

$\mathrm{F} \quad=$ Feed $(\mathrm{NaOH}$ Solution) Flow Rate, $\mathrm{kg} / \mathrm{h}$.

Vo =Mass Flow Rate for the Heating Steam, kg/h.

$\mathrm{V}_{1} \quad=$ Mass Flow Rate of the Steam vaporized from $\mathrm{NaOH}$ Solution, $\mathrm{kg} / \mathrm{h}$.

$\mathrm{L}_{1} \quad=$ Mass Flow Rate of the Product (Concentrated $\mathrm{NaOH}$ Solution), kg/h.

$\mathrm{D} \quad=$ Condensate, $\mathrm{kg} / \mathrm{h}$.

$\mathrm{H} \quad=$ Enthalpy Per Unit Mass of a Vapor Stream, kj/kg.

$\mathrm{h}=\quad=$ Enthalpy Per Unit Mass of a Liquid Stream, $\mathrm{kj} / \mathrm{kg}$.

$\lambda \quad=$ Latent Heat of Evaporation Per Unit Mass of Stream, $\mathrm{kj} / \mathrm{kg}$.

x' $\quad=$ Mass Fraction of Solute in Stream, $\mathrm{kg}$ solute / $\mathrm{kg}$ of total stream.

$\mathrm{U} \quad=$ Over-all Heat Transfer Coefficient, $\mathrm{kj} / \mathrm{m}^{2} \mathrm{hC}$.

A $=$ Heating Surface Area, $\mathrm{m}^{2}$.

$\Delta \mathrm{T}=$ Temperature Difference, $\mathrm{C}^{\circ}$.

$\mathrm{T}=$ Temperature, $\mathrm{C}^{\circ}$.

q = =Heat flux, $\mathrm{kj} / \mathrm{h}$.

Q $=$ Heat amount, $\mathrm{kj} / \mathrm{h}$.

$\mathrm{P} \quad=$ Pressure, $\operatorname{Bar}(\mathrm{a}) / \mathrm{Bar}(\mathrm{g})$. 


\section{Introduction}

This study describes the application of recycle technology for the sodium hydroxide $(\mathrm{NaOH})$, which is named as caustic soda in industrial processes, realized by means of an evaporation plant and this study also emphasizes the great importance of water pollution problem caused by the wastewater that arise from mercerizing process of textile industry.

\section{Caustic Soda (SODIUM HYDROXIDE - NaOH)}

If we consider the $\mathrm{pH}$ scale;

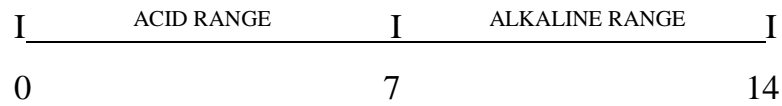

It is possible to make such a comment that acid conditions increase as the $\mathrm{pH}$ values decrease and alkaline conditions increase as the $\mathrm{pH}$ values increase. The $\mathrm{pH}$ value of caustic soda is higher than 7 and furthermore it is a highly basic material, that is, a very strong alkaline. Because of this property caustic soda is very dangerous for the environment. As we mentioned above, caustic soda is used in textile industry for mercerizing as it is used in many different industries, however, especially in our country it is discharged to the environment, e.g., rivers, seas and sewage after the process has been completed. This event is very harmful. In all developed countries, for example in European countries and U.S.A. it is entirely forbidden to discharge the caustic soda even at a $1 \%$ concentration. In all of these countries the caustic soda is recycled and reused for the subsequent process. So, both economic and environmental benefits can be provided by reusing the caustic soda for the next process, after it is recovered.

\section{Recycling of Caustic Soda by Single-Effect Evaporation at Atmospheric Pressure}

Recycling of caustic soda by evaporation is a special case of heat transfer to the boiling liquid which is $\mathrm{NaOH}$ solution. This particular heat transfer application, i.e. evaporation, is so common and important that it is treated as a separate unit operation of chemical engineering.

The main intent is to concentrate non-volatile solute (caustic soda) from the solvent, which is water. This is done by boiling of the solvent. Concentration by evaporation is normally stopped before the solute begins to precipitate.

The devices, used for evaporation operation are called as evaporators. The evaporators are classified by the number of effects. In a single - effect evaporator, steam provides energy for vaporization and the vapor product is condensed and removed from the system. In a double-effect evaporator, the vapor product of the first effect is used to provide energy for a second vaporization unit. This cascading of effect can continue for many stages. Double-effect evaporators can remove much larger amounts of solvent than is possible in a single effect.

By considering the Figure 1 the related conditions shall be as follows:

The pressure in the evaporator tank shall be 1 Bar(a).

The Caustic Soda Solution shall be raised from 5\% concentration to $20 \%$ concentration. For determining the boiling point of $\mathrm{NaOH}$ solution, Dühring Plot which is introduced in Figure 2 (Foust et al., 1959) should be used. Apart from that, for determining the enthalpy value of the $\mathrm{NaOH}$ solution the enthalpy-concentration diagram introduced in Figure 3 (Foust et al., 1959) should be used.

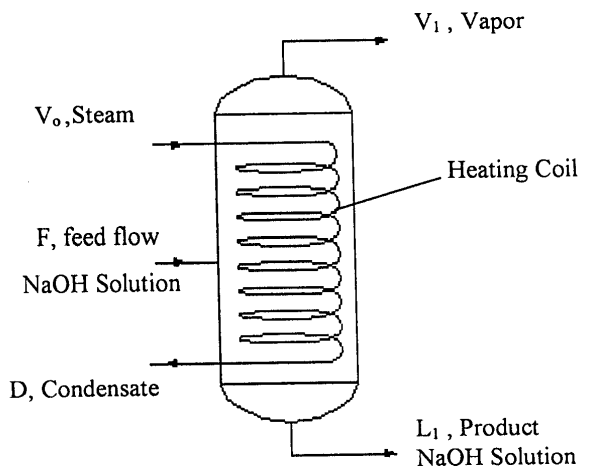

Figure 1. Recycling of caustic soda by single-effect evaporation unit.

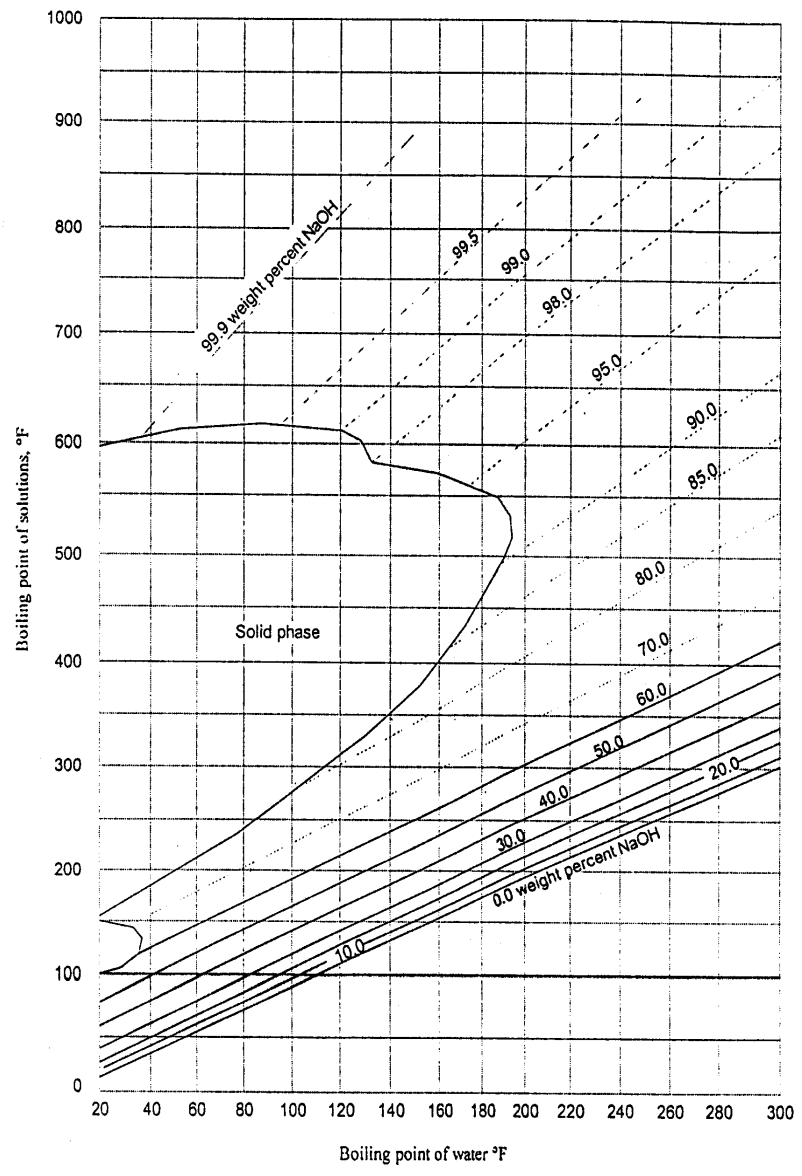

Figure. 2. Dühring lines for the $\mathrm{NaOH}-\mathrm{H}_{2} \mathrm{O}$ system (Foust et al. 1959). 


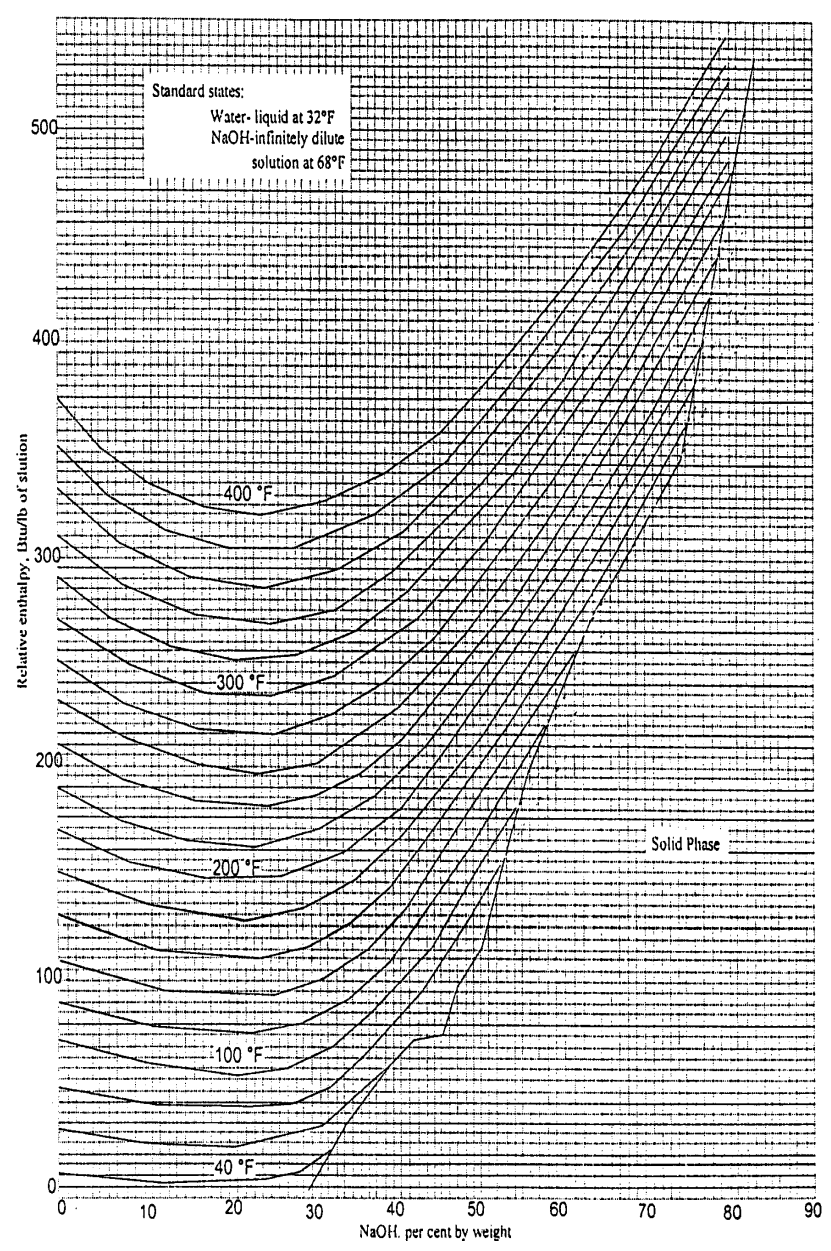

Figure 3. Enthalpy-Concentration diagram for aqueous solutions of $\mathrm{NaOH}$ under a total pressure of one atmosphere. The state for water is taken as liquid water at $32^{\circ} \mathrm{F}$ under its own vapor pressure (Foust et al.1959).

At a pressure of $1 \mathrm{Bar}(\mathrm{a})$, water boils at $100^{\circ} \mathrm{C}\left(212^{\circ} \mathrm{F}\right)$. From the Dühring Plot; the boiling point of a 20 per cent $\mathrm{NaOH}$ solution at a pressure such that water boils at $100^{\circ} \mathrm{C}$ is $110^{\circ} \mathrm{C}\left(230^{\circ} \mathrm{F}\right)$ which corresponds to a BPR (Boiling Point Rise) of $10^{\circ} \mathrm{C}\left(110^{\circ} \mathrm{C}-100^{\circ} \mathrm{C}\right)$.

Through the use of the steam tables and enthalpyconcentration diagram $\mathrm{H}_{1}$ and $\mathrm{h}_{1}$ values can be determined readily as follows:

$\mathrm{H}_{1}=2696 \mathrm{kj} / \mathrm{kg}$.

$\mathrm{h}_{1}=386 \mathrm{kj} / \mathrm{kg}$.

By using the equations for heat balance and heat transfer the steam consumption for the heating steam and the required heating surface area can be determined. In industrial applications operating the system at the atmospheric pressure is not preferred because of the high costs of operation. Instead of this, operating at low pressures (under vacuum) is preferred since the operation costs decreases sharply.

\section{Recycling of Caustic Soda by Single-effect Evaporation at Low Pressures}

When the Figure 1 is considered again;

On such an evaporation unit it is possible to determine the real operational values which are calculated by using the variable data. For realizing this aim, the four equation bellow mentioned should be examined;

1-) Equation for material balance:

$\mathrm{F}+\mathrm{V}_{\mathrm{o}}=\mathrm{V}_{1}+\mathrm{L}_{1}+\mathrm{D}$ note: $\mathrm{D}=\mathrm{V}_{\mathrm{o}}$

2-) Equation for $\mathrm{NaOH}$ solution:

$\mathrm{F} . \mathrm{XF} \mathrm{F}^{\prime}=\mathrm{L}_{1} \cdot \mathrm{X}_{1}{ }^{\prime}$

3-) Equation for heat transfer:

$\mathrm{V}_{\mathrm{o}} . \lambda_{\mathrm{vo}}=\mathrm{U} . \mathrm{A} .(-\Delta \mathrm{T})$

4-) Equation for heat balance:

$\mathrm{V}_{\mathrm{o}} \cdot \lambda_{\text {vo }}+\mathrm{F} \cdot \mathrm{h}_{\mathrm{F}}=\mathrm{V}_{1} \cdot \mathrm{H}_{1}+\mathrm{L}_{1} \cdot \mathrm{h}_{1}$

The wastewater of mercerising process generally includes the caustic soda $(\mathrm{NaOH})$ at a concentration of $5 \%$ and it is possible to recycle this material by evaporating it.

After being evaporated the caustic soda solution, the concentration increases to a considerable rate.

The general operational data of an evaporation plant for recycling of caustic soda is as follows;

The percentage of feed flow $=5 \% \mathrm{NaOH}$ solution

The temperature of feed flow $=50^{\circ} \mathrm{C}$

The mass flow rate for feed $=$ Variable between 250 $\mathrm{kg} / \mathrm{h}$ and $1000 \mathrm{~kg} / \mathrm{h}$

Steam for heating the $\mathrm{NaOH}$ solution: saturated steam within a variable range from 4 Bar(a) to $10 \operatorname{Bar}(a)$

\section{Product: $20 \% \mathrm{NaOH}$ solution.}

The evaporator tank is operated under low pressures for obtaining energy saving. If the $\mathrm{NaOH}$ solution kept under vacuum, the boiling point of the solution decreases depending upon the vacuum rate. Therefore, the energy that should be added to the $\mathrm{NaOH}$ solution for evaporation decreases. This event makes the system very economical.

Such a system mentioned here is generally operated within a vacuum range from $0,1 \mathrm{Bar}(\mathrm{a})$ to $0,4 \mathrm{Bar}(\mathrm{a})$. It is possible to operate the system under the atmospherically conditions, that is, at $1 \mathrm{Bar}(\mathrm{a})$ pressure.

Within the scope of this study both the system operating under vacuum and under atmospheric conditions shall be regarded.

In accordance with the data above, it is possible to obtain much more specific information about the evaporation plant for recycling of caustic soda.

Conditions: $F=250 \mathrm{~kg} / \mathrm{h} \quad-1000 \mathrm{~kg} / \mathrm{h}$

$50^{\circ} \mathrm{C}, 5 \% \mathrm{NaOH}$ solution.

$\mathrm{V}_{\mathrm{o}}=>4 \operatorname{bar}(\mathrm{a})-10$ bar(a). 
Vacuum rate $=>0,1$ bar(a) $-0,4$ bar(a).

$\mathrm{L}=>20 \% \mathrm{NaOH}$ solution.

If the vacuum rate for the evaporator tank is $0,1 \mathrm{Bar}(\mathrm{a})$;

At 0,1 bar(a), water boils at $45,81^{\circ} \mathrm{C}\left(114,5^{\circ} \mathrm{F}\right)$.

From the Dühring plot; the boiling point of a 20 Percent $\mathrm{NaOH}$ solution at a pressure such that water boils at $45,81^{\circ} \mathrm{C}$ is $57,22^{\circ} \mathrm{C}$ which corresponds to a BPR (Boiling Point Rise) of $11,41^{\circ} \mathrm{C}\left(57,42^{\circ} \mathrm{C}-45,81^{\circ} \mathrm{C}\right)$.

Table 1. Mass flow rates of the heating steam for $F=250$ $\mathrm{kg} / \mathrm{h}$

Pressure in the evaporator tank

\begin{tabular}{|c|c|c|c|c|c|}
\hline \multicolumn{3}{|c|}{ Atmospheric } & \multicolumn{3}{|c|}{ Below Atmospheric } \\
\hline 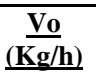 & $\begin{array}{c}1 \\
\operatorname{bar}(a)\end{array}$ & $\begin{array}{c}0,1 \\
\operatorname{bar}(\mathbf{a})\end{array}$ & $\begin{array}{c}0,2 \\
\operatorname{bar}(\mathbf{a})\end{array}$ & $\begin{array}{c}0,3 \\
\operatorname{bar}(\mathbf{a})\end{array}$ & $\begin{array}{c}0,4 \\
\operatorname{bar}(a)\end{array}$ \\
\hline $\begin{array}{c}4 \\
\operatorname{bar}(\mathbf{a})\end{array}$ & 239 & 226 & 230 & 233 & 236 \\
\hline $\begin{array}{c}5 \\
\operatorname{bar}(\mathbf{a})\end{array}$ & 242 & 228 & 234 & 236 & 239 \\
\hline $\begin{array}{c}6 \\
\operatorname{bar}(a)\end{array}$ & 244 & 231 & 236 & 239 & 242 \\
\hline $\begin{array}{c}7 \\
\operatorname{bar}(\mathbf{a})\end{array}$ & 246 & 233 & 238 & 241 & 243 \\
\hline $\begin{array}{c}8 \\
\operatorname{bar}(\mathbf{a})\end{array}$ & 248 & 235 & 241 & 243 & 246 \\
\hline $\begin{array}{c}9 \\
\operatorname{bar}(\mathbf{a})\end{array}$ & 250,9 & 237 & 243 & 245 & 247 \\
\hline $\begin{array}{c}10 \\
\operatorname{bar}(a)\end{array}$ & 252,9 & 239 & 245 & 249 & 250 \\
\hline
\end{tabular}

From the steam tables; for $0,1 \operatorname{bar}(\mathrm{a})$ and $57,22^{\circ} \mathrm{C}, \mathrm{H}_{1}$ is determined as $2606,6 \mathrm{kj} / \mathrm{kg}$. $\left(\mathrm{H}_{1}=2606,6 \mathrm{kj} / \mathrm{kg}\right)$.

From enthalpy - concentration diagram; for $20 \% \mathrm{NaOH}$ solution and $57,22^{\circ} \mathrm{C} \mathrm{h}_{1}$ is determined as $80 \mathrm{Btu} / \mathrm{lb}$. $\left(\mathrm{h}_{1}=\right.$ $186,08 \mathrm{kj} / \mathrm{kg}$ ).

The $\mathrm{H}_{1}$ and $\mathrm{h}_{1}$ values for the vacuum rates of 0,2 bar(a), 0,3 bar(a), and 0,4 bar(a) are determined through the use of same method mentioned above.

The enthalpy of the feed flow is determined by using enthalpy - concentration diagram.

For $5 \% \mathrm{NaOH}$ solution and $50^{\circ} \mathrm{C}$; the enthalpy of feed flow, $\mathrm{h}_{\mathrm{F}}$, is determined as $18648 \mathrm{kj} / \mathrm{kg}$. $\left(\mathrm{h}_{\mathrm{F}}=186,48 \mathrm{kj} / \mathrm{kg}\right)$.

With the help of the equation for heat balance;

$\mathrm{NaOH}$ balance: F. $\mathrm{X}_{\mathrm{F}}{ }^{\prime}=\mathrm{L}_{1} \cdot \mathrm{X}_{1}$,

The flow rate of product $\mathrm{L}_{1}$ values are determined.

By using the equation for material balance;

$\mathrm{F}+\mathrm{V}_{\mathrm{o}}=\mathrm{V}_{1}+\mathrm{L}_{1}+\mathrm{D}$
Since $\mathrm{D}=\mathrm{V}_{\mathrm{o}}$, the equation is $\mathrm{re}-$ arranged and then, $\mathrm{F}=\mathrm{V}_{1}$ $+\mathrm{L}_{1}$.

The $\mathrm{V}_{1}$ values can be determined by using the above equation.

By considering the equation for heat balance;

$\mathrm{V}_{\mathrm{o}} \cdot \lambda_{\text {vo }}+\mathrm{F} . \mathrm{h}_{\mathrm{F}}=\mathrm{V}_{1}+\mathrm{H}_{1}+\mathrm{L}_{1} \cdot \mathrm{h}_{1}$

From beginning to now, $\mathrm{h}_{\mathrm{F}}, \mathrm{V}_{1}, \mathrm{H}_{1}, \mathrm{~L}_{1}$ and $\mathrm{h}_{1}$ have been determined. The latent heat of vaporization $\lambda_{\text {vo }}$ can also be determined readily from the steam tables. For instance, the latent heat of vaporization for steam at a pressure of $4 \mathrm{Bar}(\mathrm{a})$ is $2134 \mathrm{kj} / \mathrm{kg}\left(\lambda_{\mathrm{vo}}=2134 \mathrm{kj} / \mathrm{kg}\right)$. Since the pressure of steam for heating purpose varies from $4 \operatorname{Bar}(\mathrm{a})$ to $10 \mathrm{bar}(\mathrm{a})$, the $\lambda_{\text {vo }}$ values can also be determined with the help of steam tables.

The only unknown in the equation for heat balance is Vo which represents the steam flow rate.

For $\mathrm{F}=250 \mathrm{~kg} / \mathrm{h}, 5 \% \mathrm{NaOH}$ solution.

For $\mathrm{L}_{1}=62 \mathrm{~kg} / \mathrm{h}, 20 \% \mathrm{NaOH}$ solution.

The Vo values can be provided by using the equation for heat balance and can also be organized as indicated Table 1;

The required heat transfer area corresponding to the above Vo values can be calculated by the use of equation for heat transfer.

$$
\mathrm{V}_{\mathrm{o}} \cdot \lambda_{\text {vo }}=\mathrm{U} . \mathrm{A} \cdot(-\Delta \mathrm{T})
$$

The only unknown in this equation is heat transfer area represented by A. However, one thing should be determined first. The total heat transfer coefficient, $\mathrm{U}$ should be determined. It is possible to use $\mathrm{U}=2000 \mathrm{kj} / \mathrm{m}^{2} \mathrm{~h}^{\circ} \mathrm{C}$ (From Chemical engineering handbook, Robert H. Perry, Cecil H. Chilton. Mc - Graw - Hill Chemical Engineering series, 1969).

The heat transfer equation was;

$$
\mathrm{V}_{\mathrm{o}} . \lambda_{\mathrm{vo}}=\text { U.A. }(-\Delta \mathrm{T})
$$

By substituting the Vo values into the heat transfer equation the heat transfer area values can be obtained readily as indicated in Table 2.

\section{For $\mathrm{F}=250 \mathrm{~kg} / \mathrm{h}, 5 \% \mathrm{NaOH}$ solution \\ $\mathrm{L}_{1}=62 \mathrm{~kg} / \mathrm{h}, 20 \% \mathrm{NaOH}$ solution}

The required mass flow rates for heating steam and the required heat transfer areas for the evaporation of caustic soda in the tank have been determined. All of the values in Table 1 and Table 2 are provided for a feed flow rate 250 $\mathrm{kg} / \mathrm{h}$, i.e., $\mathrm{F}=250 \mathrm{~kg} / \mathrm{h}$. The results obtained by using the same equations for the other feed flow rates $(400 \mathrm{~kg} / \mathrm{h}, 550$ $\mathrm{kg} / \mathrm{h}, 700 \mathrm{~kg} / \mathrm{h}, 850 \mathrm{~kg} / \mathrm{h}, 1000 \mathrm{~kg} / \mathrm{h}$ ) may be provided by using the same calculation method.

If the data obtained from this method are organized as graphics the information at the proceeding pages are viewed.

By considering the Figure 4 and Figure 5 it is possible to observe the required mass flow rates of the heating steam for evaporating the caustic soda solution. In these two figures, 
the mass flow rate of the caustic soda (feed flow) is varied from $250 \mathrm{~kg} / \mathrm{h}$ to $1000 \mathrm{~kg} / \mathrm{h}$. The pressure of the heating steam changes from 4 bar to 10 bar. The calculations are realized for both the lower operating pressures and atmospheric conditions.

Table 2. Required heating surface area values for $F=250$ $\mathrm{kg} / \mathrm{h}$

Pressure in the evaporator tank

\begin{tabular}{|c|c|c|c|c|c|}
\hline \multicolumn{4}{|c|}{ Atmospheric } & \multicolumn{2}{|c|}{ Below Atmospheric } \\
\hline$\underline{\mathbf{A}\left(\mathbf{m}^{2}\right)}$ & $\begin{array}{c}1 \\
\operatorname{bar}(\mathbf{a})\end{array}$ & $\begin{array}{c}0,1 \\
\operatorname{bar}(\mathbf{a})\end{array}$ & $\begin{array}{c}0,2 \\
\operatorname{bar}(a)\end{array}$ & $\begin{array}{c}0,3 \\
\operatorname{bar}(\mathbf{a})\end{array}$ & $\begin{array}{c}0,4 \\
\operatorname{bar}(a)\end{array}$ \\
\hline $\begin{array}{c}4 \\
\operatorname{bar}(\mathbf{a})\end{array}$ & 7,582 & 2,79 & 3,394 & 3,87 & 4,374 \\
\hline $\begin{array}{c}5 \\
\operatorname{bar}(\mathbf{a})\end{array}$ & 6,1 & 2,545 & 3 & 3,436 & 3,828 \\
\hline $\begin{array}{c}6 \\
\operatorname{bar}(\mathbf{a})\end{array}$ & 5,21 & 2,37 & 2,8 & 3,1424 & 3,45995 \\
\hline $\begin{array}{c}7 \\
\operatorname{bar}(\mathbf{a})\end{array}$ & 4,63 & 2,23 & 2,62 & 2,9 & 3,1889 \\
\hline $\begin{array}{c}8 \\
\operatorname{bar}(\mathbf{a})\end{array}$ & 4,217 & 2,127 & 2,48 & 2,7342 & 2,983 \\
\hline $\begin{array}{c}9 \\
\operatorname{bar}(\mathbf{a})\end{array}$ & 3,897 & 2 & 2,361 & 2,5934 & 2,8167 \\
\hline $\begin{array}{c}10 \\
\operatorname{bar}(\mathbf{a})\end{array}$ & 3,645 & 1,965 & 2,2699 & 2,476 & 2,6798 \\
\hline
\end{tabular}

The lower pressures considered for the calculations are 0.1 bar, 0.2 bar, 0.3 bar and 0.4 bar. The atmospheric condition is represented as 1 bar tank pressure. For a given feed flow rate, heating steam pressure and tank pressure values it is possible to see the required mass flow rate of heating steam by using these figures. It can be clearly understood from these figures that, for a constant feed flow rate and heating steam pressure value; the required mass flow rate increases as the tank pressure approaches to atmospheric conditions. Similarly, it is possible to say that the required mass flow rate decreases as the tank pressure decreases.

The required heating surface area values for the evaporation of caustic soda are given from Figure 6 to Figure 11. The feed flow changes from $250 \mathrm{~kg} / \mathrm{h}$ to $1000 \mathrm{~kg} / \mathrm{h}$. The steam pressure for heating changes from 4 bar to 10 bar and the tank pressure is also the same with mentioned at above paragraph. It can be clearly understood from these figures that, for a constant feed flow rate and heating steam pressure value; the required heating surface area value increases as the tank pressure approaches to atmospheric conditions. Similarly, it is possible to say that the required heating surface area value decreases as the tank pressure decreases.

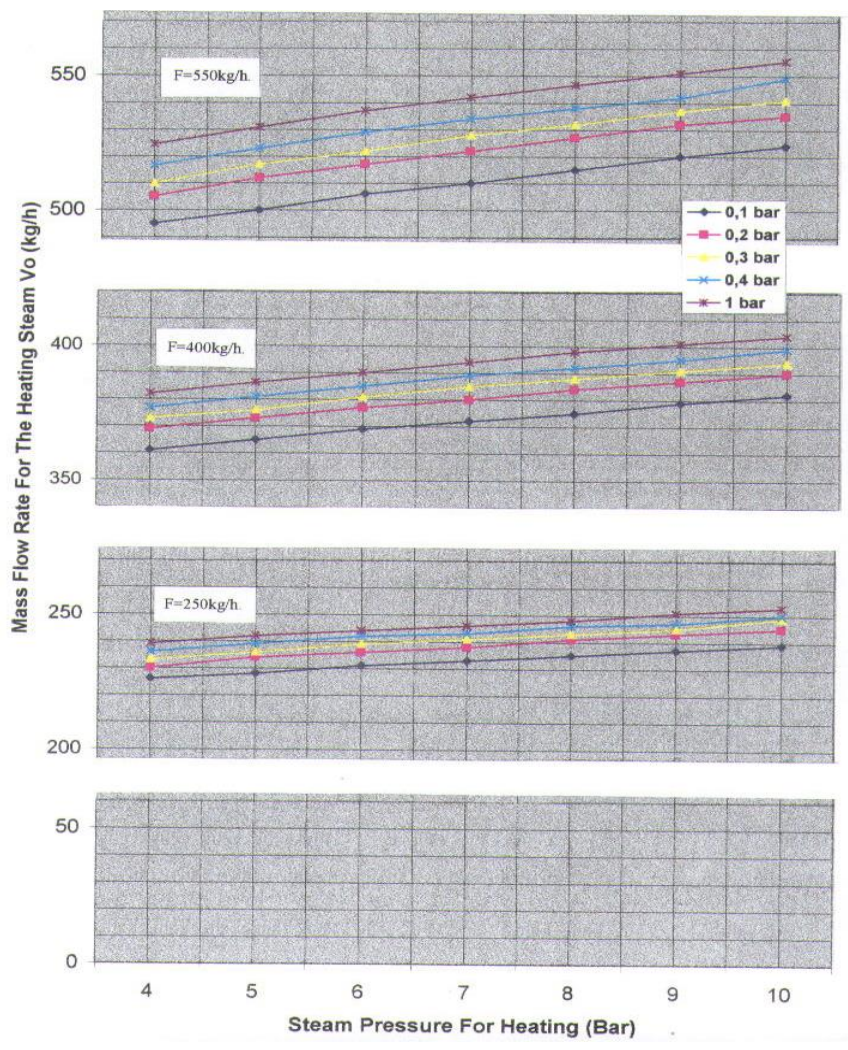

Figure 4. Mass flow rates of the heating steam for F-250, $400,500 \mathrm{~kg} / \mathrm{h}$.

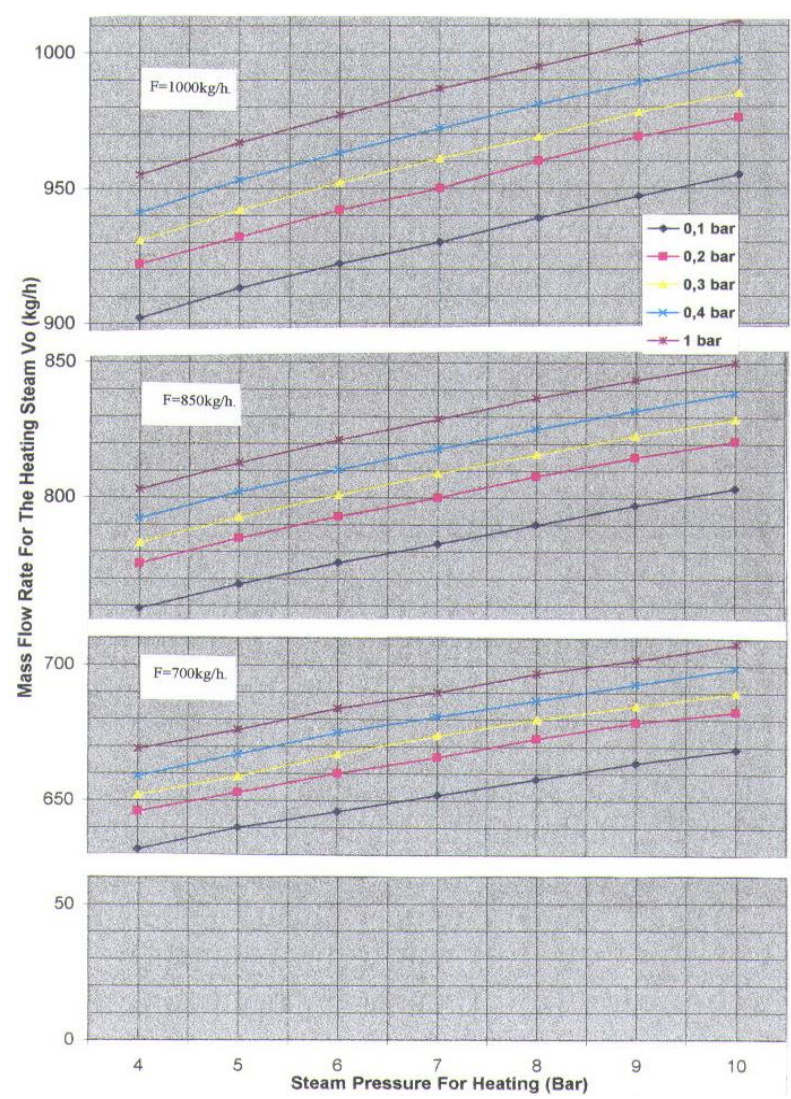

Figure 5. Mass flow rates of the heating steam for F-700, $850,1000 \mathrm{~kg} / \mathrm{h}$. 
INTERNATIONAL JOURNAL Of ENGINEERING TECHNOLOGIES-IJET

Emin Taner Elmas., Vol.3, No.3, 2017

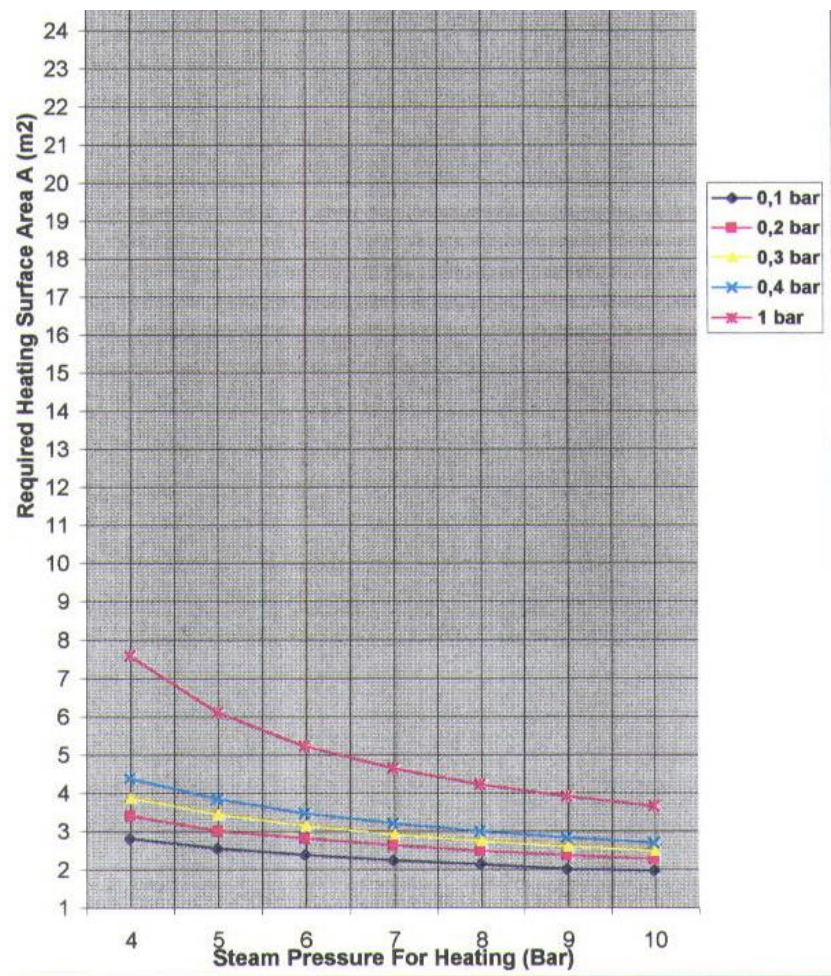

Figure 6. Required heating surface area values for $\mathrm{F}=250$ $\mathrm{kg} / \mathrm{h}$.

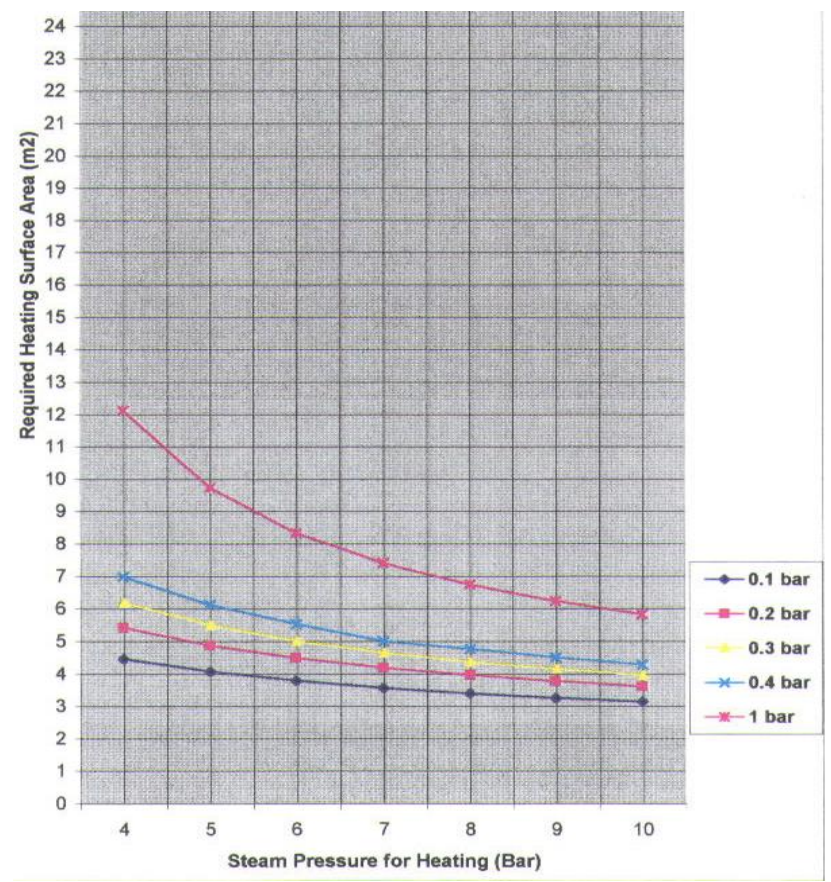

Figure 7. Required heating surface area values for $\mathrm{F}=400$ $\mathrm{kg} / \mathrm{h}$.

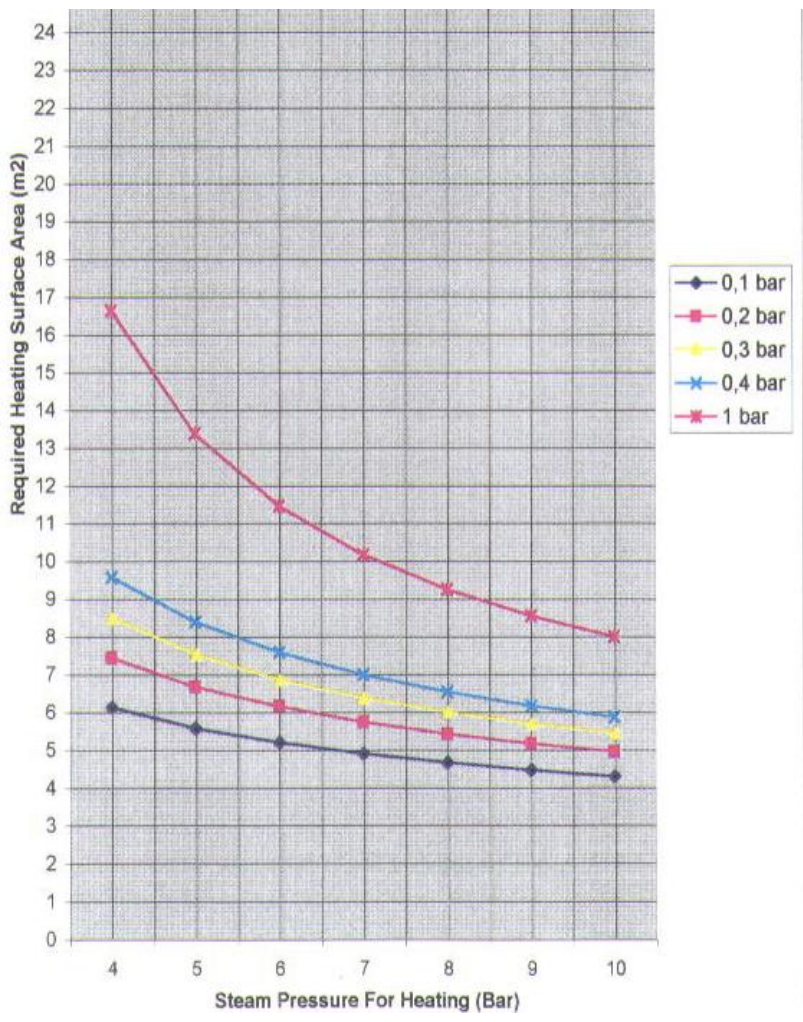

Figure 8. Required heating surface area values for $\mathrm{F}=550$ $\mathrm{kg} / \mathrm{h}$.

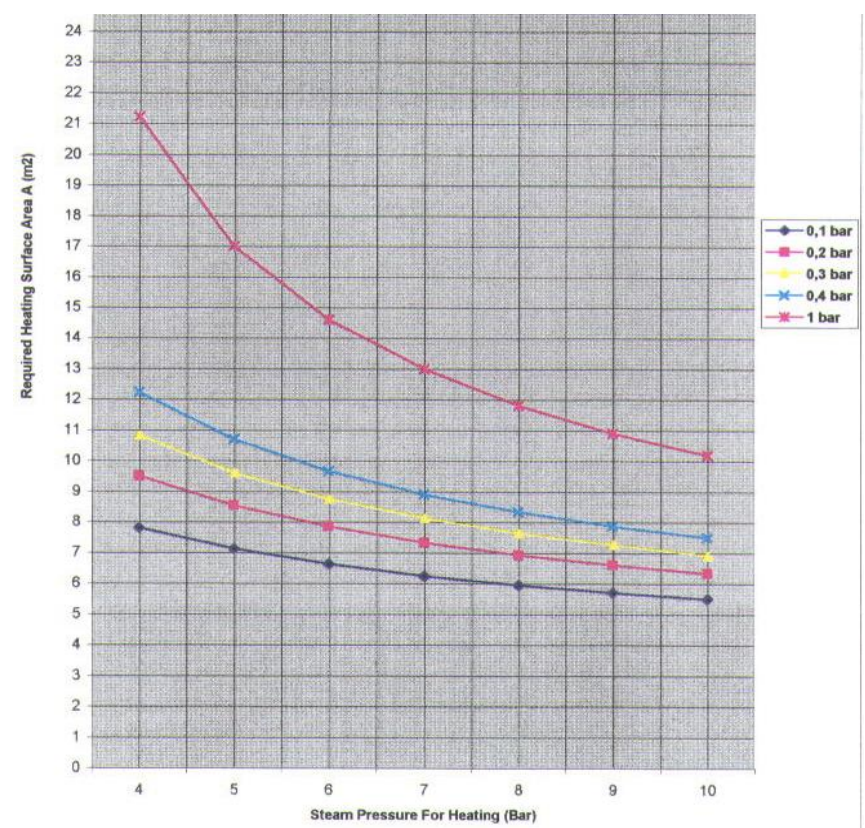

Figure 9. Required heating surface area values for $\mathrm{F}=700$ $\mathrm{kg} / \mathrm{h}$. 


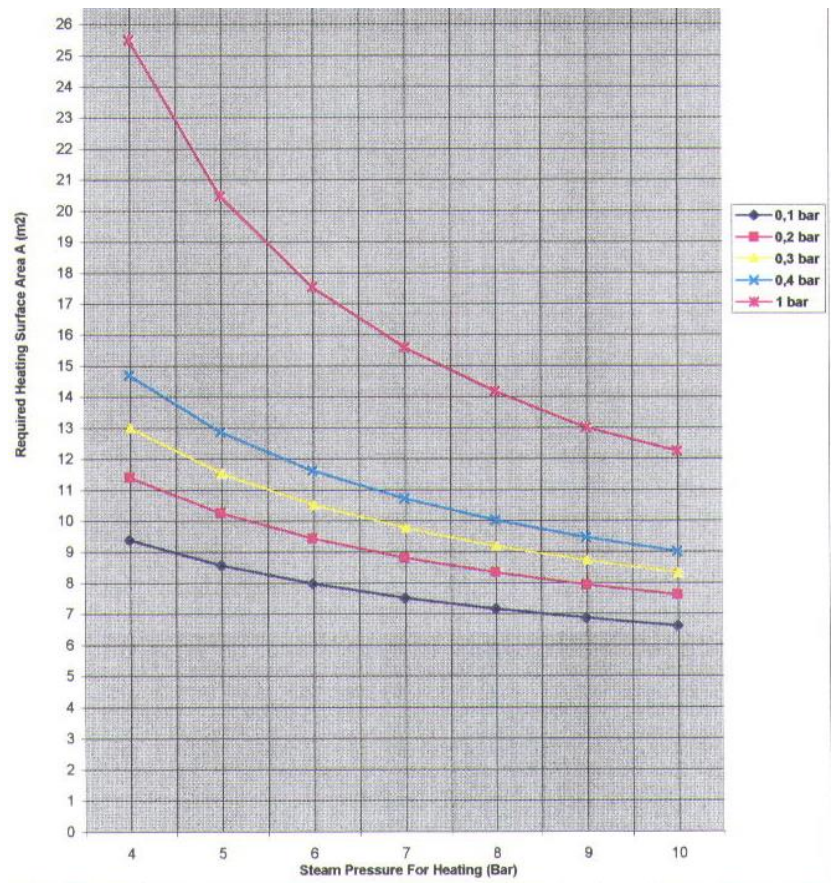

Figure 10. Required heating surface area values for $\mathrm{F}=850$ $\mathrm{kg} / \mathrm{h}$.

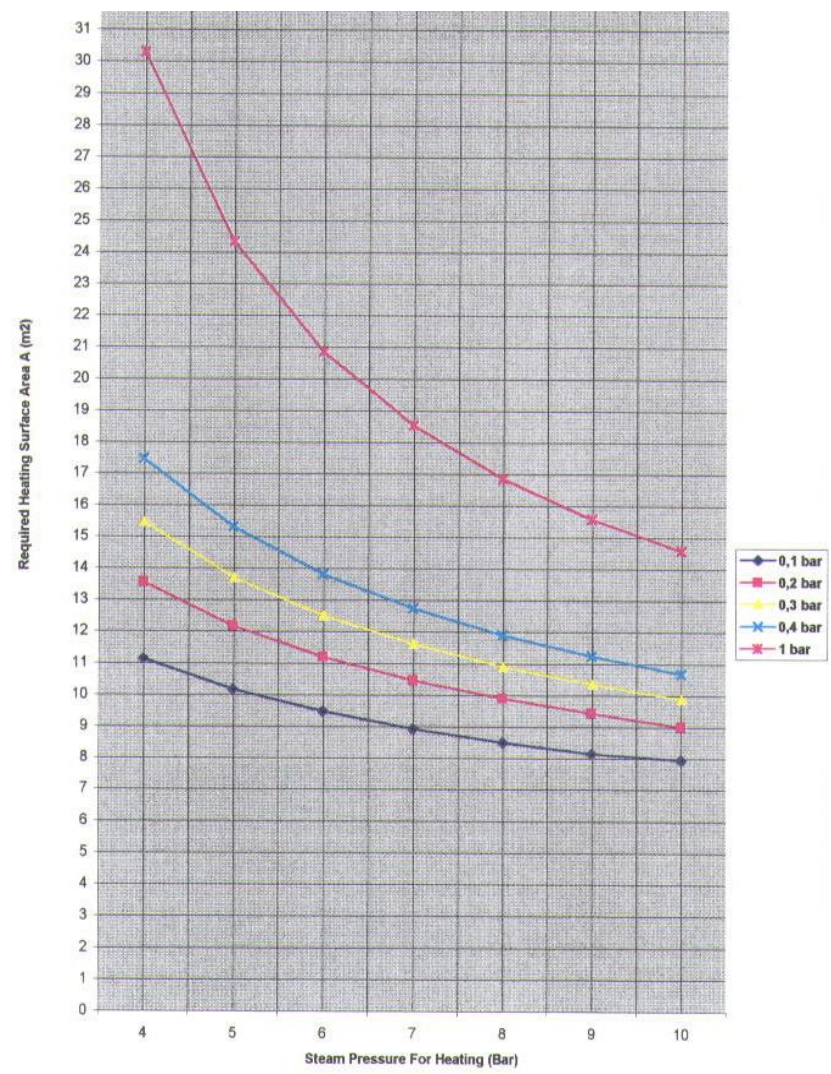

Figure 11. Required heating surface area values for $F=1000$ $\mathrm{kg} / \mathrm{h}$.

Up to now, single-effect evaporation model was considered. If double-effect evaporation is used, it is possible to decrease the steam consumption for heating, and also it is possible to increase the energy efficiency.

\section{Recycling of Caustic Soda by Double-effect Evaporation at Atmospheric and Low Pressures}

A similar calculation method is applied for the doubleeffect evaporation of caustic soda. The operational data for both single-effect and double-effect are identical. It should be noted that the calculations of the double-effect operation have been done for only a feed flow of $850 \mathrm{~kg} / \mathrm{h}$. The results can be observed on the graphics to have a much clearer idea. Figure 13 and Figure 14 explain the specific data. These figures can be used to make a comparison between the single-effect and double-effect evaporation. By using Figure 13 , it is possible to say that; for a constant feed flow rate, heating steam pressure value and constant tank pressure double-effect evaporation decreases the required mass flow rate for the heating steam. Similar to the Figure 13, Figure 14 emphasizes that the double-effect evaporation decreases the heating surface area requirement.

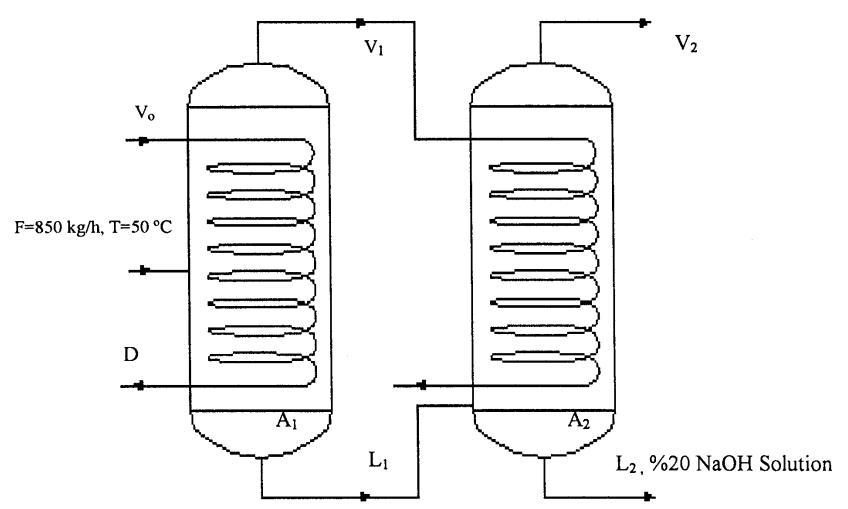

Figure 12. Recycling of caustic soda by double-effect evaporation.

\section{Conclusion and Future Work}

As it can be understood clearly from the previous explanation, two main concepts were tried to mention during this study. The first, requirements of protection of the environment from pollutants of textile industry. It is tried to explain the hazardous effects of the waste water (including caustic soda) of mercerizing which is an essential process for the textile industry.

On this basis, it has been tried to explain that caustic soda must not be discharged to the environment, e.g. to the rivers, sea and sewage even at a $1 \%$ concentration. The above concept has imposed on us to think a method that makes the recycling process of caustic soda possible. Thus, the evaporation process has been selected for recycling of caustic soda. However, the current plant system established on the evaporation operation might be required some review on. Since the system is very old, there are many energy losses on the plant.

For minimizing the energy loss and also to make such a recycling plant feasible it has been tried to operate the system under vacuum which provides energy saving and makes the plant much more economical. For this situation, an economic analysis from the aspect of energy consumption can be done. 

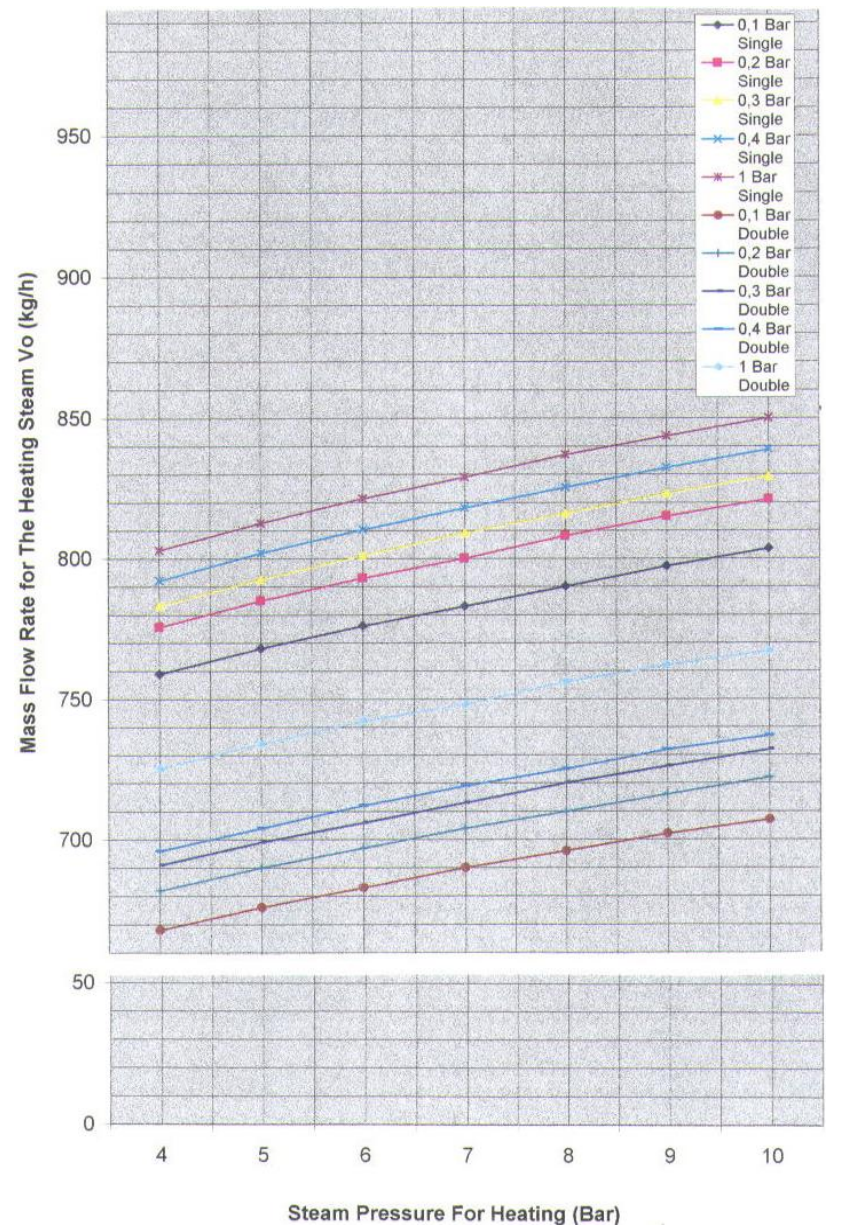

Figure 13. Mass flow rates of the heating steam for $F=850$ $\mathrm{kg} / \mathrm{h}$ (comparison of single-effect and double-effect).

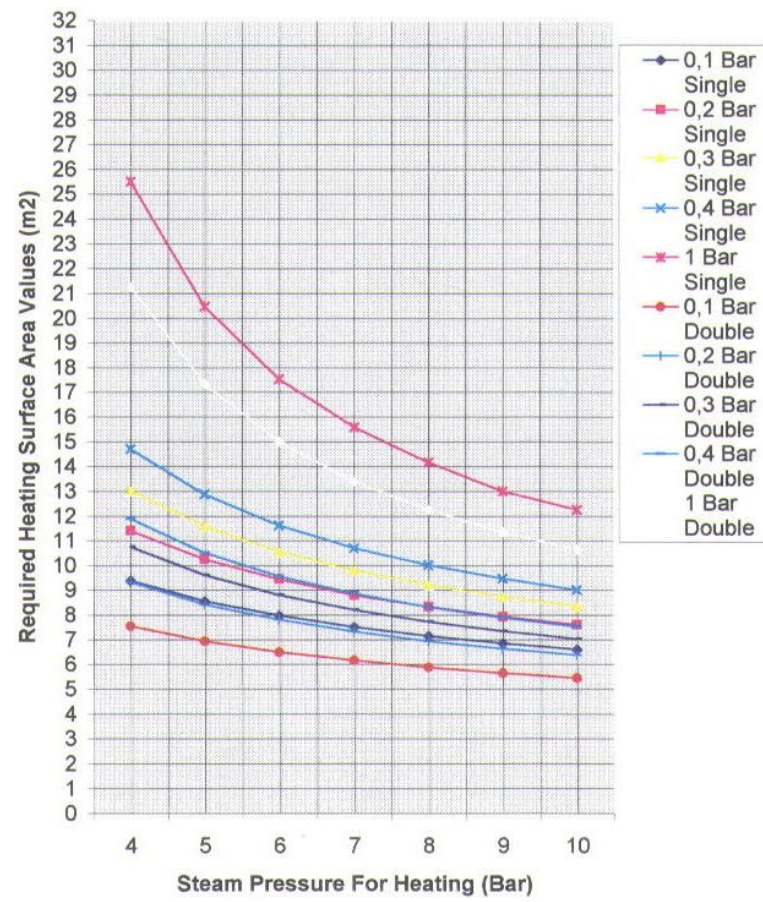

Figure 14. Comparison between the required heating surface (A1) values of double effect and the required heating area values of single effect for $\mathrm{F}=850 \mathrm{~kg} / \mathrm{h}$.
After this analysis has been realized, it is decided that an evaporation plant for recycling of caustic soda is a feasible investment. Because, after recycling the caustic soda by extracting it from the caustic soda - water solution with the help of evaporation operation, it can be used for the subsequent process. This event provides an economical profit, because caustic soda has an economical value. In addition, the environmental pollution arisen from discharging of the caustic soda solution can also be prevented.

To support these goals, the information in this study are tried to present through the use of simple graphics and figures which are available from Figure 1 to Figure 14. A thermodynamically analysis solution method is also tried to present.

To install double - effect evaporation plants instead of single - effect evaporation plants is another method for energy saving. The multiple - effect evaporation plants increases the capital cost of the system, however, since it is possible to use the vapor coming from the first stage for the subsequent stage as heating steam, this application is also a profitable method decreasing the operating costs. For both double - effect and single - effect evaporation, operating the recycling system under vacuum also increases the capital cost, furthermore this event causes and additional steam consumption for the steam - jet ejector which is used for obtaining vacuum. However, at the same time, related with this event, the boiling point of the caustic soda solution decreases considerably and the energy that must be added to the solution to be evaporated also decreases.

Here, the problem is the balance between the operating and capital costs. If it is achieved to install a balance between the capital and operating costs, it is possible to obtain much more energy efficient evaporation plants for recycling of caustic soda.

\section{References}

[1] Elmas, Emin Taner, (1999) Evaporation Plant For Recyling of Caustic Soda, M.Sc. Thesis, İzmir. (Thesis)

[2] Foust,A.S. , Wenzel,L.A. , Clump ,C.W. , Maus,L. , \& Andersen,L.B. (1959). Principles of Unit Operations. Pennsylvania : John Wiley \& Sons, Inc. (Book)

[3] Özcan,Y. (1978). Tekstil Elyaf ve Boyama Tekniği. İstanbul. (Book)

[4] Dokuz Eylül Üniv. Müh. - Mim. Fakültesi ve Ege Bölgesi Sanayi Odası. (18-19 Ekim 1983). Vakum Teknolojileri ve Vakum Metalurjisi Sempozyumu. İzmir. (Booklet)

[5] Kern,D.Q. (1950). Process Heat Transfer. Tokyo: Kögakusha Company,Ltd. (Book)

[6] Kirk - Othmer. (1970) Encylopedia of Chemical Technology. 22.Vol. 2. ed. Water (Desalination) to Zone Refining . New York: John Wiley \& Sons ,Inc. (Book Encylopedia) 
[7] Kirk - Othmer. (1967) Encylopedia of Chemical Technology. 4.Vol. 2.ed. New York: John Wiley \& Sons ,Inc. (Book - Encylopedia)

[8] Jeffries,M. , \& Mills,D. (1994). Freshwater Ecology Principles and Applications. Chichester: John Wiley \& Sons. (Book)

[9] Henglein,F.A. (1969). Chemical Technology. Karlsruhe:Pergamon Press Ltd. \& Headington Hill Hall,Oxford. (Book)
[10] Perry,R.H., \& Chilton,C.H. (1969). Chemical Engineers'Handbook.Tokyo:McGraw-Hill Kogakusha , Ltd. (Book)

[11] Badger,W.L. , \& Banchero,J.T. (1955). Introduction to Chemical Engineering. : Kogakusha Company ,Ltd. ,McGraw-Hill Book Company ,Inc. (Book)

[12] Mc.Cabe,W.L. , Smith, J.C. , \& Harriott,P. (1967). Unit Operations of Chemical Engineering. New York: McGraw-Hill Book Company. (Book) 